\title{
Development of the plate assay screening procedure for isolation of the mutants deficient in inactivation of peroxisomal enzymes in the yeast Yarrowia lipolytica
}

\author{
T. Y. Nazarko, M. J. Mala, A. A. Sibirny \\ Institute of Cell Biology, National Academy of Sciences of Ukraine \\ Drahomanov st. $14 / 16$, Lviv 79005 , Ukraine \\ E-mail: nazarko@biochem.lviv.ua
}

\begin{abstract}
The amine oxidase (AMO) plate assay screening procedure for isolation of the mutants deficient in inactivation of peroxisomal enzymes in the yeast $Y$. lipolytica has been developed. The first tagged mutants affected in the peroxisomal AMO and isocitrate lyase inactivation were generated by the insertion of a zeto-URA3 mutagenesis cassette into the genome of a zeta-free and ura3 deletion mutant strain of $Y$. lipolytica.
\end{abstract}

Introduction. Extensive peroxisome proliferation during growth on oleic acid, combined with the availability of excellent genetic tools, makes the dimorphic yeast $Y$. lipolytica a powerful model system for studying the molecular mechanisms involved in peroxisome biogenesis [1]. In glucose medium, peroxisomes become dispensable for growth and undergo autophagic vacuolar-depending degradation [2]. However, the mechanisms by which peroxisomes of $Y$. lipolytica are taken up by vacuoles during glucoseinduced degradation have not been established [3]. Mutants defective in different steps of this process can be used as a powerful approach for elucidation of the mechanisms of pexophagy, although methods for selection of such mutants in $Y$. lipolytica are not developed in details. Therefore, the aim of this study was the development of the plate assay screening procedure for isolation of the $Y$. lipolytica mutants affected in peroxisomal enzymes inactivation in glucose medium.

Materials and Methods. Strain, DNA and transformation. The Y. lipolytica zeta-free MATA ura3-302 SUC2 deletion mutant strain H222-S4 (JMY323),

(C) T. Y. NAZARKKO, M. J. MALA, A. A. SIBLRNY, 2002
JMP5 plasmid with zeta-URA3 mutagenesis cassette (MTC) (Fig. 1, $A$ ), and the primers MTC1 and MTC2, specific to the right and left borders of the MTC fragment digested by NotI from JMP5 (Fig. 1, B) [4] were kindly provided by Dr. J.-M. Nicaud, INRA Centre de Grignon, France. Amplification of MTC was performed on a GTC-2 Genetic Thermal Cycler (Precision Scientific Inc., Chicago, IL, USA). Transformation of $Y$. lipolytica was done by the $\mathrm{LiAc} / \mathrm{LiCl}$ method [5].

Media and growth conditions. Yeasts were grown at $28{ }^{\circ} \mathrm{C}$ in complete media, YPD [5] and YNBcas (YNBD with $0.2 \%$ casamino acids [6]) or in the semisynthetic $0.05 \%$ yeast extract YNB media with: 1) glucose $(1 \%)$ and ammonium sulfate $(0.5 \%)$, YNBD [6 ]; 2) ethanol $(0.5 \%)$ and ethylamine- $\mathrm{HCl}$ $(0.2 \%)$, YYEE, as the carbon and nitrogen sources. Uracil $(0.1 \mathrm{~g} / \mathrm{l})$ was added when needed. For solid media agar $(2 \%)$ was used.

Mutant isolation. The insertional mutagenesis by MTC was performed as previously described [4]. The mutants deficient in the inactivation of peroxisomal enzymes were isolated by a plate assay screening procedure (Fig. 2), developed on the basis of: 1) qualitative determination of amine oxidase (AMO) in yeast colonies $[7]$; 2) plate colony assay for visua- 


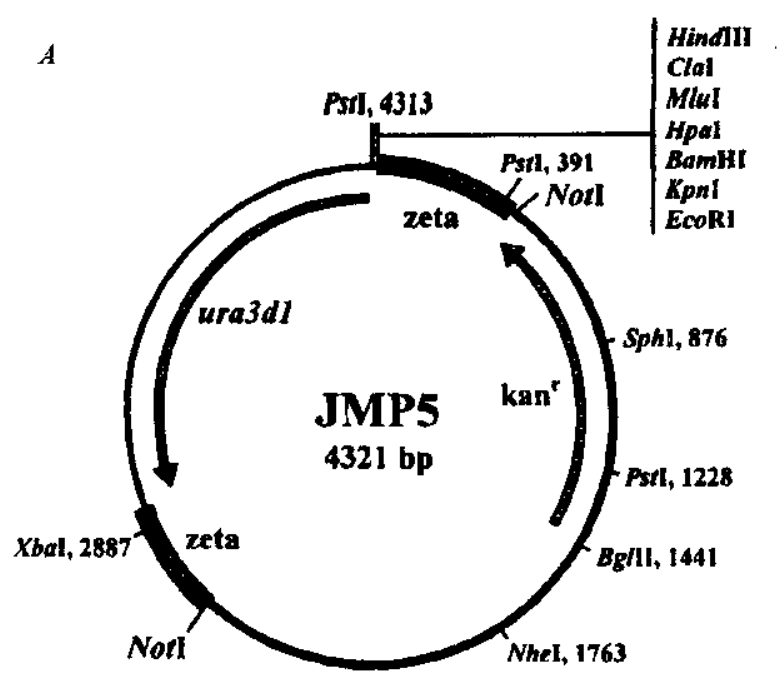

$B$

\section{MTCl GGCCGCTGTCGGGAACCGCGTTCAGG MTC2 GGCCGCACTGAAGGGCTTTGTGAGAG}

Fig. 1. Restriction map of the JMP5 plasmid with zeta-URA3 mutagenesis cassette $(A)$, and the MTC specific primers MTCl and MTC2 $(B)$, which correspond to the right and left borders of MTC fragment excised by NotI from JMP5

lization of the alcohol oxidase activity in $H$. polymorpha [8]. For mutant isolation, $\mathrm{Ura}^{+}$transformants from YNBD plates were replica plated onto YYEE plates. After incubation for $18 \mathrm{~h}$, the plates were carefully overlaid with $7-8 \mathrm{ml}$ of $0.3 \%$ top agar AMO inactivation mixture with glucose $(3 \%)$ and ammonium sulfate $(1 \%)$. After $10 \mathrm{~h}$ of incubation at $28{ }^{\circ} \mathrm{C}$ the plates were overlaid with $7-8 \mathrm{ml}$ of $0.3 \%$ top agar AMO assay mixture containing $100 \mathrm{mM}$ phosphate buffer ( $\mathrm{pH} 7.0$ ), o-dianisidine $(0.05 \%)$ as a chromogen, cetyltrimethylammonium bromide (CTAB) $(0.5 \%)$ to permeabilize cells, peroxidase $(2.3 \mathrm{u} / \mathrm{ml})$, and $4 \mathrm{mM}$ ethylamine as an AMO substrate. Reddish colored colonies due to the presence of high residual AMO activity were identified after $14 \mathrm{~h}$ of plate incubation at $28^{\circ} \mathrm{C}$.

Biochemical methods. Cell-free extracts for enzyme assays were prepared as in [9]. Protein concentrations were determined according to $[10]$, using bovine serum albumin as the standard. AMO (EC 1.4.3.4) was assayed as in [11], using the $\mathrm{pH} 7.0$ phosphate buffer and $10 \mathrm{mM}$ ethylamine as the AMO substrate. Isocitrate lyase (ICL) (EC 4.1.3.1) was assayed according to [12].
Results and Discussion. Development of the plate assay screening procedure. AMO is known to be the strictly regulated peroxisomal enzyme of $Y$. lipolytica that can be induced by ethylamine and strongly repressed by ammonium ions [2]. Besides, the exposure of acetate/oleic acid/ethylamine-grown cells to the glucose excess led to a rapid inactivation of the AMO activity [2]. Using the peroxisomal AMO as a reporter enzyme, the plate assay screening procedure for isolation of the mutants deficient in the inactivation of peroxisomal enzymes was developed (Fig. 2). First, conditions were optimized for peroxisome biogenesis and AMO induction, and for the qualitative plate assay of AMO activity in yeast colonies. The strongest and most reproducible purple coloring was obtained after $18 \mathrm{~h}$ incubation of yeast colonies on the

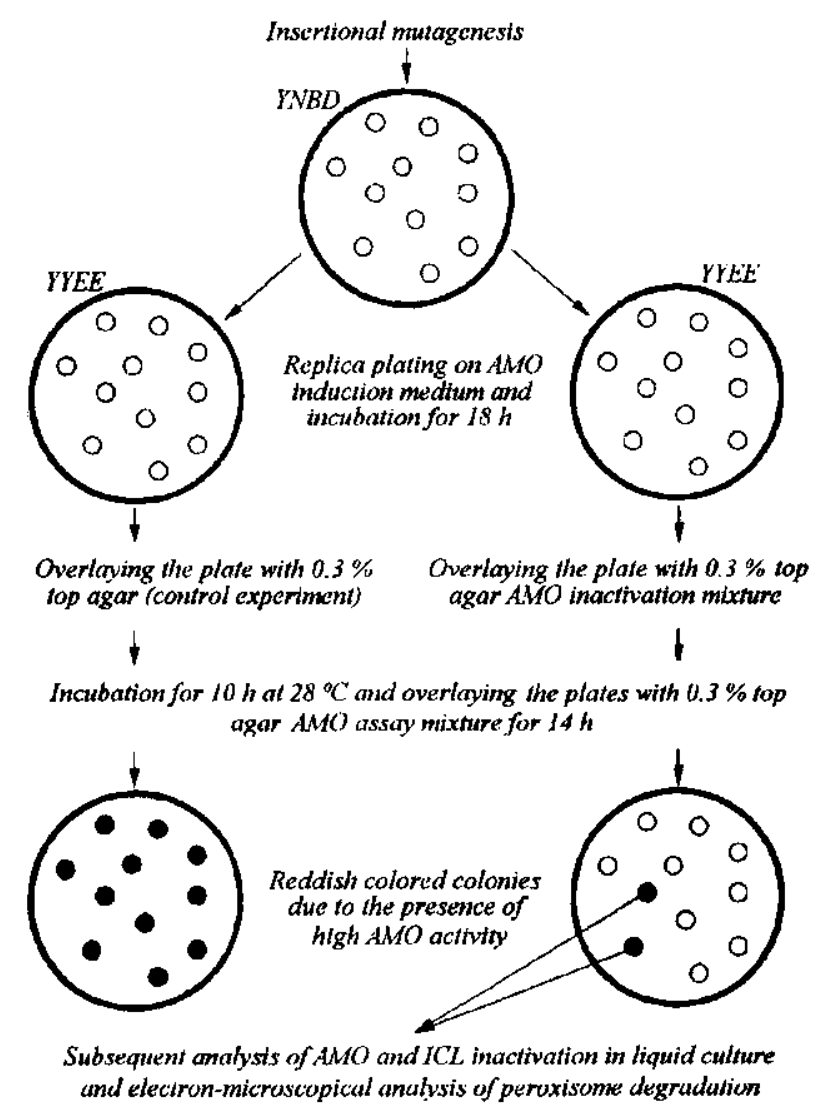

Fig. 2. Scheme of the plate assay screening procedure for isolation of the mutants deficient in inactivation of peroxisomal enzymes in the yeast $Y$. lipolytica 


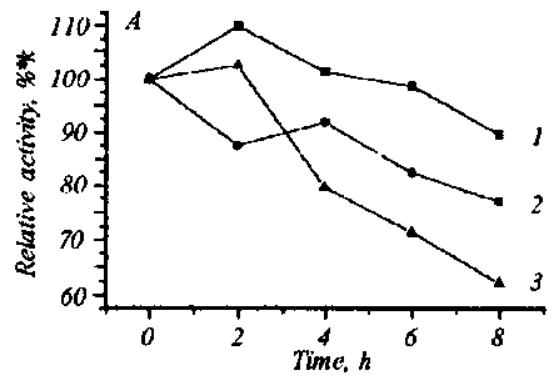

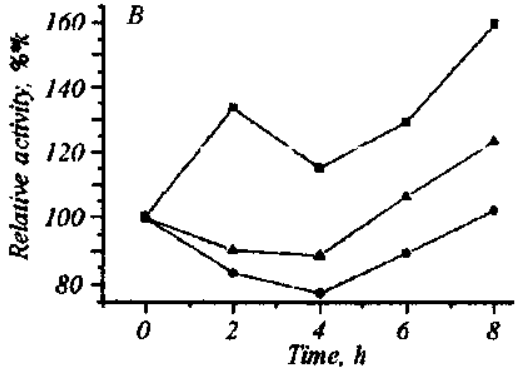

Fig. 3. Amine oxidase $(A)$ and isocitrate lyase $(B)$ inactivation in cell-free extracts of $Y$ lipolytica Ain mutants after shifting exponentially growing cells from YYEE to YNBD medium without yeast extract: $I-$ Ain $4 ; 2$ Ain7; 3 - H222-S4. Uracil was added for all strains to both media. Data were corrected for growth of the celts in glucose medium
YYEE induction medium. The YYEE medium, supplemented with oleic acid $(0.5 \%)$, YNO medium $(0.67 \%$ YNB, $0.4 \%$ sodium acetate, $0.5 \%$ oleic acid, $0.1 \%$ Tween 20 and $0.2 \%$ ethylamine- $\mathrm{HCl}$ [2]) and YNO medium without oleic acid produced weaker staining. $0.25-0.5 \%$ ethanol in YYEE had 1.5-2 times stronger inducing effect than ethanol in concentrations of $1-2 \% .0 .05 \%$ yeast extract in YYEE provided better growth of colonies and had no influence on the AMO induction rate. Using CTAB instead of digitonin as a permeabilizing agent for $Y$. lipolytica provided more reproducible results. The best combination of maximum color intensity and minimum turbidity corresponded to the $0.5 \%$ of CTAB and phosphate buffer (pH 7.0) instead of Tris- $\mathrm{HCl}$ buffer ( $\mathrm{pH} \mathrm{8.0)}$ in the AMO assay mixture.

Next, the procedure for inactivation of peroxisomal AMO in yeast colonies was elaborated. All approaches developed previously gave poor results with $Y$. lipolytica colonies.

For example, inactivation by replica plating on glucose medium, used by Titorenko et al. [8] could not be applied in case of dimorphic colonies of $Y$. lipolytica, because of insufficient amount of biomass for determination of the AMO activity even after $6 \mathrm{~h}$ incubation of replicated colonies on the fresh YYEE medium. The inactivation by overlaying induction plates with liquid glucose medium and its subsequent removing after $6-8 \mathrm{~h}$, developed by Gunkel et al. [2], is not acceptable in case of YYEE, the alcohol medium without oleic acid, because of washing out the colony material. To solve this problem, we developed an approach of double overlaying (Fig. 2). The YYEE plates should be overlaid, first, with $0.3 \%$ top agar AMO inactivation mixture with $3 \%$ glucose (to induce pexophagy) and $1 \%$ ammonium sulfate (to repress de novo AMO synthesis). It was previously shown that ammonia ions of such concentration had no inhibitory effect on AMO activity when added to the activity assay mixture for $\mathrm{H} 222-\mathrm{S} 4$ cells induced on the YYEE medium. After appropriate incubation time, the plates should be overlaid with $0.3 \%$ top agar AMO assay mixture with doubled concentrations of phosphate buffer and ethylamine (as in «Materials and Methods»).

Using this approach, the reliable difference in staining between colonies which were or were not subjected to the AMO inactivation was achieved (Fig. 2). At least $8-10 \mathrm{~h}$ incubation at $28{ }^{\circ} \mathrm{C}$ between overlaying with the AMO inactivation mixture and subsequent pouring with the AMO assay mixture should be applied for almost total AMO inactivation in the plate assay developed.

Isolation of the mutants deficient in inactivation of peroxisomal enzymes. The tagged mutants affected in the AMO inactivation were generated by insertion of the PCR amplified MTC (Fig. 1) into the genome of H222-S4 strain of $Y$. lipolytica [4]. It has been demonstrated, that the MTC insertion occurs randomly by non-homologous recombination and that mutant phenotypes are due to the genes' disruption with the integration cassette [4]. More than 2000 $\mathrm{Ura}^{+}$transformants were analyzed and 10 clones identified as defective in the AMO inactivation (Ain ${ }^{-}$) after 3 sequential rounds of plate screening. For two of them, namely Ain4 and Ain7, the defect of AMO inactivation was confirmed in liquid culture by determining the enzyme activity in cell-free extracts (Fig. 3, A). The Ain4 mutant was simultaneously affected in inactivation of the second peroxisomal enzyme, ICL (Fig. 3, B). Peroxisome degradation in these strains is the subject of further biochemical and morphological analysis. To identify the disrupted gene in the ain4 mutant the regions flanking the integrated MTC will be sequenced using PCR walking method [4].

Acknowledgements. We thank Oleh V. Stasyk and Dr. Jean-Marc Nicaud for helpful discussion. This work was supported by grant INTAS 99-00788 «Principles of peroxisome biogenesis and degradation in yeasts». 


\section{T. Ю. Назарко, М. Є. Мала, А. А. Сибірний}

Розробленкя методу масового відбору мутантів з пошкодженою інактивацією пероксисомних ферментів дріжджів Yarrowia lipolytica

\section{Резюме}

Розроблено метод масового відбору мутантів дріжджів Y. lipolytica $з$ поикодженою інактивацією пероксисомних ферментів. Отримано периі мутанти з блоком інактивації пероксисомних амінооксидази та ізоцитратліази шиляхом інсерції касети zеta-URA3 в геном вільного віd zеta-елементіо делеційного мутанта ura3 Y. lipolytica.

\section{T. Ю. Назарко, М. Е. Мала, А. А. Сибирный}

Разработка метода массового отбора мутантов с поврежденной инактивацией пероксисомньх ферментов дрожжей Yarrowia lipolytica

\section{Резкоме}

Разработан метод массового отбора мутантов дрохжей $Y$. lipolytica c nоврехденной инактивацией пероксисомньх ферментов. Получены первые мутанты с блоком инактивации пероксисомных аминооксидазы и изоцитратлиазы путем инсерции кассеты zеta-URA3 в геном свободного от zеtа-елементов делеционного мутанта ura3 $Y$. lipolytica.

\section{REFERENCES}

1. Titorenko Y. I., Smith J. J., Szilard R. K., Rachubinski R. A. Peroxisome biogenesis in the yeast Yarrowia lipolytica // Cell Biochem. and Biophys. $-2000 .-32 .-P .21-26$.

2. Gunkel K., van der Klei I. J., Barth G., Veenhuis $M$. Selective peroxisome degradation in Yarrowia lipolytica after a shift of cells from acetate/oleate/ethylamine into glucose/ammonium sulfate-containing media // FEBS Lett.-1999.-451.-P. 14.

3. Veenhuis M., Salomons F. A., Van Der Klei I. J. Peroxisome biogenesis and degradation in yeast: a structure/function analysis // Microsc. Res. Tech.-2000.-51.-P. 584-600.
4. Mauersberger S., Wang H. J., Gaillardin C., Barth G., Nicaud $J$. $M$. Insertional mutagenesis in the $n$-alkane-assimilating yeast Yarrowia lipolytica: generation of tagged mutations in genes involved in hydrophobic substrate utilization // J. Bacteriol.2001.-183.-P. 5102-5109.

5. Barth G., Gaillardin C. Yarrowia lipolytica // Nonconventional Yeasts in Biotechnology / Ed. K. Wolf.-Bertin: Springer, 1996.-P. 313-388.

6. Wang H. J., Le Dall M. T., Wache Y., Laroche C., Belin J. $M$., Gaillardin C., Nicaud J. M. Evaluation of acyl coenzyme A oxidase (AOX) isozyme function in the n-alkane-assimilating yeast Yarrowia lipolytica // J. Bacteriol.-1999.-181.P. $5140-5148$.

7. Sibirny A. A., Titorenko V. I. The method for qualitative determination of alcohol oxidase and catalase in yeast colonies // Ukrainsky Biokhimichny Zhurnal.-1986.-58, N 5.P. $65-68$.

8. Titorenko V. I., Keizer I., Harder W., Veenhuis $M$. Isolation and characterization of mutants impaired in the selective degradation of peroxisomes in the yeast Hansenula polymorpha // J. Bacteriol.-1995. - 177.-P. 357-363.

9. Johnson M. A., Waterham H. R., Ksheminska G. P., Fayura L. R., Cereghino J. L., Stasyk O. V., Veenhuis M., Kulachkousky A. R., Sibirny A. A., Cregg J. M. Positive selection of novel peroxisome biogenesis-defective mutants of the yeast Pichia pastoris // Genetics. $\rightarrow$ 1999. - 151.-P. 1379-1391.

10. Lowry O. H., Rosebrough N. J., Farr A. L, Randall, R. J. Protein measurement with the Folin phenol reagent // J. Biol. Chem. - 1951.-193.-P. 265-275.

11. Sibirny A. A., Titorenko V. I., Ubiyvovk V. M. Differences in the regulation of biosynthesis of cytosolic superoxide dismutase and methanol oxidation enzymes in yeasts // Biokhimiya.1987.-52.-P. 469-473.

12. Reeves H. C., Rabin R., Wegener W. C., Ajl S. J. Assays of enzymes of tricarboxylic acid and glyoxylate cycles // Methods in Microbiology / Eds J. R. Norris, D. W. Ribbons.-New York: Acad. press, 1971.-Vol. 6A.-P. 425-462.

удК 576.311.34

Надійшла до редакції 12.11.01 